\title{
Prevalence of Lewis Blood Group among Bangladeshi Population
}

\author{
*TF Dipta ${ }^{1}$, H Rahman², A Khatun ${ }^{3}$, MA Islam ${ }^{4}$ \\ ${ }^{1}$ Dr. Tashmim Farhana Dipta. Associate Professor, Haematology \& Transfusion Medicine, Head Transfusion \\ Medicine Department, BIRDEM General Hospital and Ibrahim Medical College \\ ${ }^{2}$ Dr. Hafizur Rahman Incharge, Clinical Haematology Laboratory, ICDDR, B, Dhaka \\ ${ }^{3}$ Prof. Dr. Ayesha Khatun. Professor, Transfusion Medicine Department, BSMMU, Dhaka \\ ${ }^{4}$ Prof. Dr. Md. Ashadul Islam. Professor and Chairman, Transfusion Medicine Department, BSMMU, Dhaka \\ *Corresponding author \\ Date of submission: 02 February 2016 \\ Date of acceptance: 17 May 2016
}

\begin{abstract}
Background: The Lewis system differs from all other blood group systems. It is primarily a system of soluble antigens originate in the tissue of body secretions, such as saliva (glycoprotein) and in plasma (glycolipid) respectively. The $\mathrm{ABH}$ secretor status influences red cells of Lewis phenotype and this phenotype may be modified by the ABO phenotype.

Methodology: A cross sectional study was done to determine the presence of Lewis antigens in patients and voluntary donor's blood and observe the agglutination pattern during blood cross matching. In this study 350 blood samples were tested by hemagglutination -monoclonal antibodies.

Result: Our study showed, Lewis antibody was detected in $50.8 \%$ cases. The presence of anti-Leb was more frequent $(69.7 \%)$ than anti-Lea in association with $\mathrm{ABO}$ blood group. Lewis anti-Leb was most common in $\mathrm{O}$ group (75.0\%) followed by group-A (69.0\%) where as anti-Lea was predominant in B (37.7\%) followed by $\mathrm{AB}$ $(33.3 \%)$. Moreover among Lewis phenotypes, Le $(\mathrm{a}-\mathrm{b}+)$ was present in $35.4 \%$ cases, $\mathrm{Le}(\mathrm{a}+\mathrm{b}-)$ in $15.1 \%$ and Le $(a+b+)$ was rare $(0.3 \%)$. Phenotype Le (a-b-) represents all negative cases 172 in number $(49.2 \%)$.

Conclusion: Presence of Lewis antibody cause irregular agglutination interfering with interpretation of compatibility testing. So the patients with multiple transfusions or having atypical or irregular antibodies should routinely test for Lewis blood group antibodies to avoid untoward reactions.
\end{abstract}

Key Words: Lewis blood group, Cross match, Bangladesh

\section{Introduction}

The Lewis blood group antigens Lewis a $\left(\mathrm{Le}^{\mathrm{a}}\right)$ and Lewis $b\left(\mathrm{Le}^{\mathrm{b}}\right)$ are carbohydrate antigens related to the $\mathrm{ABO}$ blood group antigen that are synthesized in epithelial tissues and adsorbed to the surface of red blood cells; these antigens can also be detected in saliva and other secretions, as well as on cells of mucosal epithelia ${ }^{1-3}$.This system was first described in 1946 by Mourant when anti-Lea was found; subsequently anti-Le ${ }^{b}$ was reported by Anderson in $1948^{1,2}$. The term Lewis refers to the family name of individuals suffering from a red cell incompatibility problem that lead to the discovering of this blood group ${ }^{3}$. The antigens are poorly developed at birth and the phenotype of red cells from cord blood is usually Le (a-b-). Subsequently Lea develops first, followed by $\mathrm{Le}^{\mathrm{b}}$ when the relevant Lewis and secretor genes are present. A definite adult Lewis phenotype may not be reached until the age of 4-5 years ${ }^{4}$. Unlike other blood group antigens, Lewis antigens of red cells apparently are acquired by absorption from plasma: The Le (a-) or Le (b-) cells can acquire antigens Le $(a+)$ or Le $(b+)$ when suspended in plasma containing $\mathrm{Le}^{\mathrm{a}}$ or $\mathrm{Le}^{\mathrm{b}}$ substance ${ }^{1}$. Phenotype Le $(a+b+)$ has been incriminated as a transient phase, which may change to phenotype Le $(a-b+)$ in adult life. Lewis system peculiarity is that, anti-Lea detects an antigen, which appears to be inherited as a Mendelian recessive manner, while other red cell antigens are considered co-dominant. Distribution of Lewis blood group phenotypes vary among different population and ethnic groups ${ }^{2,4}$. Le antibodies anti$\mathrm{Le}^{\mathrm{a}}$ and anti-Le ${ }^{\mathrm{b}}$, are naturally occurring IgM type cold antibodies having high thermal amplitude $\left(4^{0} \mathrm{C}\right.$ to $37^{\circ} \mathrm{C}$ ). Majority of these antibodies is generally weak 
and reacts best at $20^{0} \mathrm{C}^{5}$. Because of the high molecular weight they are unable to cross the placenta. IgG type is rare. Le antigen is poorly formed on the fetal and neonatal red cells, Lewis antibodies usually not implicated in hemolytic disease of fetus or newborn. Anti-Lea commonly and rarely anti-Leb may cause hemolysis in vivo, and the magnitude of red cell destruction is rarely of clinical importance ${ }^{6}$. However, there are case reports where naturally occurring warm-reacting $\operatorname{IgM}$ Lea antibodies have caused hemolytic transfusion reactions (HTR), one reported acute HTR caused by IgM Lea alloantibody and one case reported IgG Lewis antibodies developed following blood transfusion ${ }^{7-9}$. It is shown that the presence of Le antibodies may cause some difficulties in cross-match techniques in blood transfusion $^{6,10}$. The aim of this study was to detect the presence of Lewis antibodies and their phenotype, compare the agglutination patterns appearing in routine blood testing for cross matching and also ABO blood group among samples having Lewis antibodies.

\section{Materials \& Method}

This cross sectional study was conducted over three years in the Clinical Hematology Laboratory and Blood Bank \& Transfusion Services of the Laboratory Science Division of the International Centre for Diarrhoeal Disease Research, Bangladesh (ICDDR'B) between June 2005 and July 2008. Randomly selected blood samples were taken either from patients requesting blood group and cross match as well as from voluntary blood donors who were screened for safe blood transfusion. The tests were performed using saline agglutination (Hemagglutination) technique at room temperature using monoclonal antibodies available commercially (BIOSCOT LIMITED, Livingston, UK). Each step of the test procedure was followed meticulously as per manufacturer's instruction. Agglutination of red cells occurs in two stages. The first stage consists of the binding of antibody to antigens on the red cells (sensitization) and the second stage involves agglutination of sensitized red cells. Reagent activity was confirmed with known positive and negative cells (Organon Teknika, Panel-10 cells). In addition, auto-agglutination using patients own cells and serum was set up side by side in each batch as a control. The results of the tests were read macroscopically and confirmed microscopically. Results were then analyzed to determine the proportions of Lewis antigens and its relative frequency relating to $\mathrm{ABO}$ and $\mathrm{Rh}$ blood groups.

\section{Results}

Record revealed variable age of 350 study subjects, from 1 to 75 years, including 50 children $(14.3 \%)$ under 5 years of age and 177 male adults (50.6\%), however, Lewis antibody was present in only 178 (50.8\%) cases. Moreover among Lewis phenotypes, of positive cases, the $\operatorname{Le}(a-b+)$ was found in $124(35.3 \%)$ cases, $\operatorname{Le}(a+b)$ in $53(15.1 \%)$ cases and the phenotype $\operatorname{Le}(a+b+)$ in one case $(0.3 \%)$ only. The cases negative for Lewis antibody represent the Le (a-b-) phenotype in 172 $(49.2 \%)$ subjects (Table-I). The presence of Lewis antibodies in relation to ABO system was shown in Table 2 . Among the Lewis antibody positive cases, antiLeb was predominant $(69.7 \%)$ followed by anti-Lea $(29.8 \%)$. and only one case had anti-Le ${ }^{\mathrm{a}}+\mathrm{b}(0.6 \%)$. Table-II also showed, the anti-Le ${ }^{b}$ was more common (75\%) in Lewis positive ABO groups, predominantly in "O" group individuals .Frequency pattern of anti-Leb in association with $\mathrm{ABO}$ blood group system was $\mathrm{O}>\mathrm{A}>$ $A B>B$ whereas, pattern of anti-Lea was $B>A B>A>0$ with predominance in $B$ group (37.7\%). Agglutination of red cells in presence of anti-Lewis antibodies exhibited a characteristic stringy appearance resembling chains of cells when observed microscopically (Figure 1), while incompatible cross match showed an area of irregular agglutination or rouleaux of red cells (Figure 2).

Table 1: Prevalence pattern of the phenotypes of Lewis antibodies $(\mathrm{n}=350)$

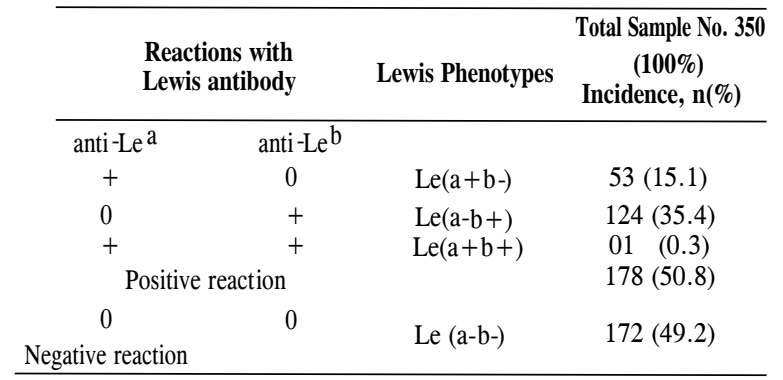

Table 2: ABO grouping of blood samples having Lewis antibodies $(\mathrm{n}=178)$

\begin{tabular}{ccccc}
\hline $\begin{array}{c}\text { ABO } \\
\text { system }\end{array}$ & \multicolumn{2}{c}{ No. positive Lewis antibody } & $\begin{array}{c}\text { Frequency of Lewis } \\
\text { antibody in relation to } \\
\text { ABO blood group }\end{array}$ \\
\hline & $\begin{array}{c}\text { Anti-Le } \\
\text { No. (\%) }\end{array}$ & $\begin{array}{c}\text { Anti-Le } \\
\text { No. (\%) }\end{array}$ & $\begin{array}{c}\text { Anti-Le } \\
\text { No. (\%) }\end{array}$ & $\begin{array}{c}\text { Total } \\
\text { No. (\%) }\end{array}$ \\
A & $08(27.6)$ & $20(69.0)$ & $01(3.4)$ & $29(16.3)$ \\
B & $20(37.7)$ & $33(62.3)$ & - & $53(29.8)$ \\
AB & $04(33.3)$ & $08(66.7)$ & - & $12(6.7)$ \\
O & $21(25.0)$ & $63(75.0)$ & - & $84(47.2)$ \\
Total & $\mathbf{5 3 ( 2 9 . 7 )}$ & $\mathbf{1 2 4 ( 6 9 . 7 )}$ & $\mathbf{0 1}(\mathbf{( 0 . 6 )}$ & $\mathbf{1 7 8}(\mathbf{1 0 0 )}$ \\
\hline
\end{tabular}




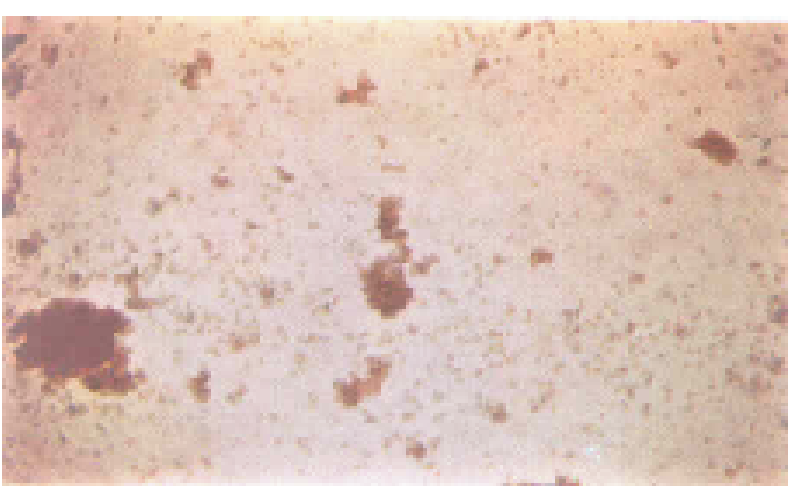

Figure 1: Characteristic stringy appearance (microscopic) of antiLewis agglutination.

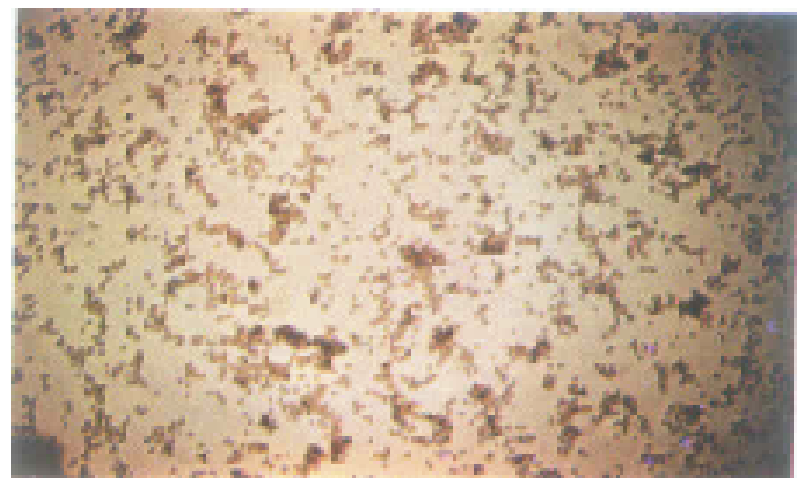

Figure. 2: Microscopic appearance of rouleaux formation.

\section{Discussion}

The Lewis antigen system has three different phenotypes; $\operatorname{Le}(\mathrm{a}+\mathrm{b}-)$ (these individuals have the nonsecretor phenotype); $\operatorname{Le}(\mathrm{a}-\mathrm{b}+)$, in which $\mathrm{a}$ fucosyltransferase converts Lea to Leb (these individuals have the secretor phenotype); or Le(a-b-), in which there is a failure to express either antigen (these individuals can be either secretors or non-secretors) ${ }^{11}$ so, the phenotypes $\operatorname{Le}(a-b+)$ and $\operatorname{Le}(a+b+)$ are secretor groups ${ }^{12}$. In our study we found that, the Lewis antigens $\left(\mathrm{Le}^{\mathrm{a}}\right.$ and $\left.\mathrm{Le}^{\mathrm{b}}\right)$ are rarely of clinical significance due to presence of abundant Lewis substances (Le) in serum, which may neutralize the antibodies in vitro during the cross match or in vivo during transfusion and the gradual elution of Lewis antigens from the donor red cells ${ }^{9}$. However; Lewis antibodies have the potential to be clinically significant when it causes in vitro hemolysis during serological testing. Once these in vitro hemolytic antibodies are detected, they should be considered clinically relevant, and antigen-negative blood should be selected for transfusion ${ }^{10,11}$. Potent Lewis antibodies will sensitize red cells to agglutination by anti-IgM but very seldom to agglutination by anti-IgG. Study showed the phenotype Le (a-b-) is substantially commoner in
TF Dipta, H Rahman, A Khatun et al

black people than in white people; approximately $25 \%$ compared with 8\%; and the phenotype Le(a-b+) is less commoner in black than in white with $54 \%$ compared to $71 \%$ and also showed reversed result with us. The frequency of $\mathrm{ABH}$ secretors in Australian Aborigines and Polynesians is $98 \%$ and the phenotype $\operatorname{Le}(\mathrm{a}+\mathrm{b}+)$, with strong Lea, is common in Australian Aborigines, Indonesians, Japanese, Polynesians and Taiwanese but, the $\operatorname{Le}(\mathrm{a}+\mathrm{b}-)$ phenotype is absent or rare also showed difference ${ }^{12,14}$. The Lewis antibodies in young children may not reflect the true phenotype because all infants are Le (a-b-) at birth ${ }^{12,13}$. RBC expressing the Le $(a+b+)$ phenotype in infants eventually will be converted into Le $(a-b+)$ expression by two years of age so, in our study we found, $49.1 \%$ were Le (a-b- $)^{11,17}$. The higher frequency $(49.1 \%)$ of phenotype Le (a-b-) in our study may be attributed to inclusion of children less than 5 years, whereas, in a Dhaka based study on children with ETEC diarrhea, $59 \%$ were Le $(\mathrm{a}-\mathrm{b}+), 26 \%$ were of Le $(a+b-)$ phenotype and $15 \%$ had a Le (a-b-) blood group phenotype as determined by both blood and saliva tests which has similar phenotypic pattern with us, whereas, the percentage of the Le $(\mathrm{a}-\mathrm{b}+)$ phenotype in our study $(35.4 \%)$ was much lower than that in Caucasians $(\sim 70$ $80 \%$ ) but similar to the Lewis antigen distribution in adult Indians and in African population ${ }^{11,17,18}$. Lewis antibodies always bind complement and convenient to detect by indirect antibody Test (IAT), using a reagent containing anti-complement and more enhanced using Low ionic strength (LISS) or by enzyme treated cells ${ }^{14}$. Study showed there is higher frequency of the phenotype Le (a-b-) in patients with cancer of the bladder seems to be due to the conversion of Le- positive to Le- negative with advanced disease. Donors of anti-Le ${ }^{\mathrm{a}}$ belong more frequently to groups $\mathrm{A}, \mathrm{B}$ or $\mathrm{AB}$ shows weakly expressed Lewis antigen, however, the risk of haemolytic transfusion reaction may occur if, Le $(a+)$ red cells of group $\mathrm{O}$, which have more Lewis antigens than A or B cells, has been selected for a patient whose serum contains potent anti- Le ${ }^{a}$. Thus, Lewis antibodies, particularly anti- Lea can cause rapid destruction of small volume of $\mathrm{Le}(\mathrm{a}+)$ red cells and results positive indirect anti-globulin test (IAT) with anti- complement at $37^{\circ} \mathrm{C}$, whereas, some anti-Leb sera fail to react with $\mathrm{A}_{1}$ cells although they react strongly with cells of group $\mathrm{O}$ or $\mathrm{A}_{2}$. In our study we found that in group $\mathrm{O}$ study subjects anti- Lea was $25 \%$ and anti- Leb was $75 \%$. In countries in South- East Asia, Lewis antibodies may be more potent than Europeans to cause severe haemolytic transfusion reactions ${ }^{12-14}$. Study also reported presence of auto- anti-Lea in a multi-transfused Le $(\mathrm{a}-\mathrm{b}+)$ patient with carcinoma of the oesophagus where, the patient's own red calls partially adsorbed the antibody ${ }^{14}$. 
Prevalence of Lewis Blood Group among

However, least difficulty caused by Lewis antibodies in blood transfusion may be partially due to effect of Lewis substances in the donor 's plasma which neutralizes corresponding antibodies in the recipient's plasma and partially due to the chameleon- like behavior of red cells which is within a few days of transfusion assume the phenotype of the recipient ${ }^{1,14}$. Cross match is done to ensure the safety of the recipient by detecting the complete, incomplete or irregular antibodies present in the donor cells or serum. Usually an area of irregular agglutination or rouleaux of red cells leads to confusion in interpreting compatibility test whether it is really a mismatch or due to presence of an artifact. A mismatch may occur due to an error in grouping or due to presence of atypical or irregular antibodies in the patient or donor's serum. Presence of strong agglutinins in donor and/or recipient serum might pose difficulty in cross matching to laboratory professionals, especially when the patient requires immediate and frequent multiple blood transfusions ${ }^{1,14}$. So in testing suspected Lewis antibodies, the use of fresh cells and short incubation period with skilled and experienced professionalism is needed to detect agglutination reactions and to avoid any untoward reactions.

\section{Conclusion}

Our study showed Lewis antibody in $50.8 \%$ cases and as we know presence of strong agglutinins in donor and/or recipient serum might pose difficulty in cross matching, detection and identification of irregular antibodies are of clinical importance to the patients requiring multiple transfusions who already possess atypical or irregular antibodies (alloimmunization).

\section{Acknowledgement}

Authors gratefully acknowledge to all the paediatric patients, their parents and all voluntary blood donors who were willingly participated in this study.

Conflict of interest: We have no conflict of interest.

\section{References}

1. Klein HG, Anstee DJ. In Mollison's blood transfusion in clinical medicine (11th ed): ABO, Lewis and P groups and Ii antigens. Blackwell Publishing, UK, 2005; p. 114- 162.

2. Lewis blood group system: Hyland Reference Manual of Immunohematology. Immunohematology division, Hyland Laboratories, $4^{\text {th }}$ edn. Los Angeles, California. 1966; 48-50.

3. Ajit Varki, Richard Cummings, Jeffrey Esko, Hudson Freeze, Gerald Hart, Jamey Marth. Lewis blood group structures: Essentials of Glycobiology. La Jolaa, Califonia, 1999; 72-96.
4. Sulakshan Pasricha. Lewis antibodies in pregnant Indian, British \& Pakistani women. Indian J Med Res. June 1983: 850-53.

5. H.M. Bhatia. Occurrence of Lewis antibodies in Bombay. Ind Jour Med Res. October 10, 1965; 971-74.

6. Harmening DM, Taghizadeh M. The Lewis System. In Harmening DM (3rd ed): Modern Blood Banking and Transfusion Practices. FA Davis, Philadelphia 1994, p. 133145.

7. Beenu Thakral, Ashish Jain, Karan Saluja, Ratti Ram Sharma, T. shyam K. Singh, Neelam Marwaha. Acute Haemolytic transfusion reaction by Lea alloantibody. Wiley InterScience 2006; 81(10): 807-808

8. Matson GA, Coe J, Swanson J. Haemolytic transfusion reaction due to anti Lea. Blood 1955;10:1236-1240.

9. Brendemoen OJ, Aas K. Haemolytic transfusion reaction probably cause by anti-Lea. ACTA Med Scand 1952; 141:458.

10. Cheng MS, Lukomskyj L. Lewis antibody following a massive blood transfusion. Vox Sang 1989; 59:155-156

11. Arifuzzaman M, Ahmed T, Rahman MA, Chowdhury F, Rashu $\mathrm{R}$, et al. Individuals with $\mathrm{Le}(\mathrm{a}+\mathrm{b} 2)$ Blood Group Have Increased Susceptibility to Symptomatic Vibrio cholerae 01 Infection. PLoS Negl Trop Dis (Dec, 2011); 5(12): e1413, p. 1-8.

12. S Akhter, GM Kibria, NR Akhter, MM Habibullah, SMK Islam, M Zakariah. . ABO and Lewis Blood Grouping with ABH Secretor and Non-secretor Status: A Cross Sectional Study in Dhaka. Faridpur Med. Coll. J. Jan 2011; 6(1):38-40.

13. M. Contreras, G. Daniels. Antigens in Human blood. A. Victor Hoffbrand, Daniel Catovsky, Edward G.D. Tuddenham. Postgraduate Haematology. Fifth ed. Blackwell Publishing, Oxford: 2005; 225-48.

14. S.M. Knowles. Blood cell antigens and antibodies: erythrocytes, platelets and granulocytes. S Mitchell Lewis, Barbara J Bain, Imelda Bates. Dacie and Lewis Practical Haematology. Ninth ed. Churchill Livingstone, London: 2001. P. 429-69.

15. Kathryn E. Webert, Howard H.G. Chan, J.W. Smith, N.M. Heddle, J.C. Kelton. Red cell, Platelet, and White cell antigens. Wintrobe's Clinical Hematology. 10th ed, Vol. 1; p. 791-824.

16. Technical Manual, 10th ed. Arlington, VA, American Association of Blood Banks 1990; p 1- 665.

17. Ahmed T, Lundgren A, Arifuzzaman M, Qadri F, Teneberg S, et al. Children with the $\mathrm{Le}(\mathrm{a}+\mathrm{b} 2)$ blood group have increased susceptibility to diarrhea caused by enterotoxigenic Escherichia coli expressing colonizationfactor I group fimbriae. Infect Immun (2009) , 77(5): 2059-2064.

18. Pasricha, S. Lewis antibodies in pregnant Indian, British \& Pakistani women. The Indian journal of medical research1983, 77:850-853. 